\begin{tabular}{|c|c|c|c|c|c|c|}
\hline \multirow{4}{*}{ Impact Factor: } & ISRA (India) & $=3.117$ & SIS (USA) & $=0.912$ & ICV (Poland) & $=6.630$ \\
\hline & ISI (Dubai, UAE & $=0.829$ & РИНЦ (Russia) & $=0.156$ & PIF (India) & $=1.940$ \\
\hline & GIF (Australia) & $=0.564$ & ESJI (KZ) & $=8.716$ & IBI (India) & $=4.260$ \\
\hline & JIF & $=1.500$ & SJIF (Morocco) & $=5.667$ & OAJI (USA) & $=0.350$ \\
\hline
\end{tabular}

\begin{tabular}{|c|c|}
\hline $\begin{array}{l}\text { SOI: } \frac{1.1 / \mathrm{T}}{\mathrm{S}} \\
\text { International St } \\
\text { Theoretical } \boldsymbol{\&}\end{array}$ & $\begin{array}{l}\frac{\mathrm{AS}}{\mathrm{DOI}} \text { 10.15863/TAS } \\
\text { cientific Journal } \\
\text { Applied Science }\end{array}$ \\
\hline p-ISSN: 2308-4944 (print) & e-ISSN: $2409-0085$ (online) \\
\hline Year: 2019 Issue: 05 & Volume: 73 \\
\hline Published: 25.05.2019 & http://T-Science.org \\
\hline
\end{tabular}

QR - Issue

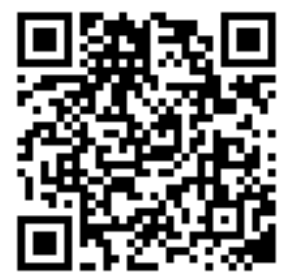

Khamidillo Murodillaevich Lutfillaev

Doctor of philosopy (Ph.D.)

Researcher of Al-Beruni Institute of Oriental Studies of Academy of Sciences of the Republic of Uzbekistan

\title{
TAFSEERS OF THE QURAN, WRITTEN BY SCIENTISTS OF CENTRAL
}

\section{ASIA}

Abstract: The article deals with the tafseers which were written in Central Asia. It also provides information about their distribution and their authors. The article covers the latest researches on Tafseers and their importance will be discussed.

Key words: Quran, mufassir, manuscript, tafseer, Central Asia.

Language: Russian

Citation: Lutfillaev, K. M. (2019). Tafseers of the Quran, written by scientists of central Asia. ISJ Theoretical \& Applied Science, 05 (73), 310-313.

Soi: http://s-o-i.org/1.1/TAS-05-73-43 Doi: crossef https://dx.doi.org/10.15863/TAS.2019.05.73.43

\section{ТАФСИРЫ КОРАНА, НАПИСАННЫЕ УЧЕНЫМИ ЦЕНТРАЛЬНОЙ АЗИИ}

Аннотация: В статье рассматриваются тафсеры, написанные в Центральной Азии. Он также предоставляет информацию об их распространении и их авторах. Статья посвящена последним исследованиям тафсеров, и их важность будет обсуждаться.

Ключевые слова: Коран, муфассир, рукопись, тафсир, Центральной Азии.

\section{Введение}

Коран на протяжении веков являлся важным источником в формировании философских, этических и правовых воззрений для всех народов, исповедующих ислам, в том числе и для мусульман Центральной Азии. Однако, уже VIIVIII веках, в связи со сложностью восприятия и понимания аятов и выражений Корана, появилась насущная необходимость написания тафсиров, т.е. комментариев к нему.

Начиная с первых этапов расспространения ислама в Центральной Азии, подобно другим регионам входивших в Халифат, появился интерес к Корану и другим наукам, связанным с тафсиром и из представителей местных народов вышел ряд ученых муфассиров. В с этого времени появляется традиция написания тафсиров к Корану.

\section{Основная часть}

В процессе ознакомления с дошедшими до нас тафсирами становится известным, что большинство тафсиров IX-XII веков, созданных авторами из Центральной Азии, написаны на арабском языке, считавшимся в то время языком науки. Согласны данным произведения Хаджи
Халифы «Кашф аз-зунун ан-асамил кутуб ва-лфунун» («(Книга) разрешающая сомнения о названиях книг и наук»), первым написанным в Центральной Азии тафсиром было произведение «Тафсир-и Кабир», автором которого был Абу Абдаллах Мухаммад ибн Исмаил ибн Ибрахим ибн ал-Мугира ибн Бардизба ал-Джуъфи алБухари (ум. 870). Но к сожалени, данное произведение до сих пор не найдено. Мы предполагаем, что этот тафсир был написан на арабском языке, так как Имам Бухари все свои произведения писал на арабском языке.

Традиция написания тафсиров в данном регионе продолжалась имела место и в дальнейшем, что выразилось в написании значительного числа тафсиров на арабском языке. В частности, произведение Имама Абу Мансура Мухаммада ибн Махмуда ал-Матуриди (870-944) «Таъвилат ал-Куръан» («Комментарии Корана») также считается одним из первых, написанных в Центральной Азии тафсиров. По мнению Ш. Зиядова, иследовавшего это произведение, Матуриди является первым среди ученых ханафитского мазхаба, написавших тафсир. Данное произведение оказало большое 


\begin{tabular}{|c|c|c|c|c|c|c|}
\hline \multirow{4}{*}{ Impact Factor: } & ISRA (India) & $=3.117$ & SIS (USA) & $=0.912$ & ICV (Poland) & $=6.630$ \\
\hline & ISI (Dubai, UAI & $=0.829$ & РИНЦ (Russia & $=0.156$ & PIF (India) & $=1.940$ \\
\hline & GIF (Australia) & $=0.564$ & ESJI (KZ) & $=8.716$ & IBI (India) & $=4.260$ \\
\hline & JIF & $=1.500$ & SJIF (Morocco & $=5.667$ & OAJI (USA) & $=0.350$ \\
\hline
\end{tabular}

положительное влияние не только на Мавераннахрскую школу тафсира, но и на школу калама. Матуриди при написании своего тафсира опирался на три источника, т.е. Коран, хадис и мнения прежних муфассиров[1].

Произведение «Бахр ал-улум» («Море знаний») имама Абуллайса Насра ибн Мухаммада ибн Ахмада ибн Ибрахима ас-Самарканди (911985) считается одним из совершенных тафсиров. В произведении аяты Корана комментируются согласно метода маъсур и оно считается первым тафсиром, написанном в этом направлении. Рукописи этого произведения имеются в библиотеках и рукописехранилищах Берлина, Мюнхена, Лейдена, Иерусалима, Туниса, Истанбула, Санкт-Петербурга и Ташкента. Критический текст данного тафсира был подготовлен докторами университета ал-Азхар (Египет) Мухаммадам Муаввазом Абдулмаджидом и Абдулмаджидом ан-Нути на основании рукописей, хранящихся в Египте и Эдинбурге, и был издан в трех томах в Бейруте в 1993 году. В последние годы в Узбекистане над данным произведением ведет свои исследовании А.Абдуллаев, которые собрал ценные сведения, относящиеся к рукописям, хранящимся в рукописехранилищах мира[2].

В процессе ознакомления с тафсирами, хранящимися в фонде Института востоковедения АН РУз, мы также ознакомились с трактатом Абу Али ибн Сины (ум. 1037) «Тафсир», написанным на арабском языке и который нашел свое отражение в каталоге рукописей института. Несколько рукописей данного произведения хранятся в различных рукописехранилищах мира, в том числе и в составе сборника «Маджмуа-и расаил-и хукама» в фонде ИВАН РУз (№2385). Так в нем дается комментарий таким сурам как «Фотиха», «Аъла», «Ихлас», «Фалак» и «Нас». Комментарий суры «Ихлас» был издан на турецком языке в 1910 году в журнале «Сират алмустаким», издававшимся в Станбуле.

Произведение Наджмиддина Абу Хафса Умара ибн Мухаммада ан-Насафи ас-Самарканди (ум.1142) «Тайсир фи-т-тафсир» («Облегчающий в тафсире») также считается одним из наменитых в исламском мире тафсиров.

Произведение Имама Джаруллаха Абулкасима Махмуда ибн Умара Мухаммада ибн Умара Замахшари (ум. 1144) «Кашшаф ал-хакаики ва уйун ал-акавили фи вужух ат-таъвил» («Открывающий на пути таъвила сущность слов и истину»), более известное в исламском мире под кратким названием «Тафсир-и кашшаф», отличается от других в отношении филологического анализа. Исламские ученые, высоко оценив этот тафсир, отметили, что “если бы не было «Кашшафа», то значения Корана так и остались бы нераскрытыми”. Некоторые сведения о «Тафсир-и кашшаф» приведены в статьях египетского иследователя Джалалиддина асСуюти, узбекистанских ученых Р.Абидова, У.Уватова, Н.Сулеймановой[3-5]. Кроме них имеются научные работы таких ученых как Б.З.Халидов, Е.А.Резван, Д.А.Агиус, также касающиеся этого вопроса[6-9]. Подобно этому, краткая характеристика этого произведения нашло свое место и в изданных каталогах[10-11].

Произведение «Тафсир-и Захиди» Шайха Захида Абу Насра Ахмада ибн Хасана ибн Ахмада Зари Сулаймани Давраджаки Бухари (XII в.)[12] написано в Бухаре в 1125 году. Произведение имеет большое число рукописных и литографных копий, и только в одном фонде ИВАН РУз имеется его 9 рукописных экземпляра.

Произведение Фахриддина Абу Абдуллаха Мухаммада ибн Умара ибн Хусейна Рази (11491209) «Мафатих ал-гайб» («Ключи сокрытого») считается самым известным тафсиров, выполнего на основе метода раъй. В нем автор больше внимания уделял естественным наукам, в особенности астрономии[13]. Произведение издано в восьми томах и широко распространено в мире.

Произведение Насир ад-дина Абдуллаха ибн Умара ал-Байзави (ум.1316) «Анвар ат-танзил ва асрар ат-таъвил» («Лучи ниспосланного и тайны таъвила») также считается одним из совершенных тафсиров. Данный труд широко известен в мусульманском мире как «Тафсир-и Байзави» и «Тафсир-и кази Байзави». Произведение также переведено на персидский язык, но автор перевода до сих пор неизвестен. В фонде ИВАН РУз хранится ряд его экземпляров, переписанных и изданных в различное время [14].

Одним из написанных в Центральной Азии тафсиров является произведение Абулбараката Абдуллаха ибн Ахмада ибн Махмуд ан-Насафи (ум. 1310) [15] «Мадарик ат-танзил хакакик аттаъвил» («Достижение ниспосланного и истины разъяснения»), более известное как «Тафсир-и Насафи». Как отмечается в исследованиях, данное произведение Насафи является сокращенной версией произведений «Тафсир-и Кашшаф» и «Тафсир-и Байзави». Оно было издано в четырех томах.

По-видимому в эпоху правления Темуридов возросла потребность в тафсире. Так как в этот период было создано много тафсиров и их присущей особенность было то, что они были написаны на персидском языке и на основе метода тафсир-и ишари. Если сначала были написаны комментарии к некоторым сурам, то по мере увеличения их количества расширялся и объем тафсиров. Одним из первых созданных в эту эпоху тафсиров было произведение «Тафсир-и Ходжа Мухаммад Парса», написанное в 823(1420-1421) году в Бухаре. Автором произведения являлся 


\begin{tabular}{|c|c|c|c|c|c|c|}
\hline \multirow{4}{*}{ Impact Factor: } & ISRA (India) & $=3.117$ & SIS (USA) & $=0.912$ & ICV (Poland) & $=6.630$ \\
\hline & ISI (Dubai, UAI & $=0.829$ & РИНЦ (Russia & $=0.156$ & PIF (India) & $=1.940$ \\
\hline & GIF (Australia) & $=0.564$ & ESJI (KZ) & $=8.716$ & IBI (India) & $=4.260$ \\
\hline & JIF & $=1.500$ & SJIF (Morocco & $=5.667$ & OAJI (USA) & $=0.350$ \\
\hline
\end{tabular}

глава суфийского тариката накшбандия Мухаммад ибн Мухаммад ибн Махмуд Хафиз Бухари (более известен как Ходжа Мухаммад Парса), к перу которого принадлежат ряд произведений по суфизму[16]. В данном тафсире дается комментарий 8 сурам Корана как «Фатиха», «Кадр», «Баййина», «Залзала», «Вал-адият», «Кориъа», «Такасур», «Аср» и «Хумаза». Один рукописный экземпляр этой рукописи хранится в фонде ИВАН РУз под номером №2180.

Автором «Тафсир-и Чархи» является известный ученый суфий Яъкуб ибн Усман ибн Махмуд ибн Мухаммад Газнави Чархи (ум. 1447), написавший также несколько произведений по учению накшбандия и исламским наукам[17]. В своем произведении «Тафсир-и Чархи» автор прокоментировал 49 сур Корана (сура Фатиха, от суры Мулк до конца Корана). На сегодня в мире имеется много рукописных и литографных экземпляров данного произведения. Только в фонде ИВАН РУз имеется свыше 25 рукописей данного произведения, большинство из которых имеет научное описание[18]. Кроме того «Тафсири Чархи» в 993/1585 году был переведен на тюркский язык Хаджи Хамадани по просьбе Сайида Падшахаджи. Перевод хранится в фонде ИВАН РУз под номером №5174.

Более совершенный по отношению к упомянутым выше произведениям тафсир на арабском языке, включающий в себя комментарий 66 сур Корана (от суры Каф до конца Корана), принадлежит перу Абдурахмана Джами (14141492). Хотя в науке Джами известен как автор многих произведений, но мало кто знает, что он написал и тафсир. В результате ознакомления с тафсирами, хранящимися в фонде ИВАН РУз, нам удалось выявить тафсир, принадлежащий перу Джами. На сегодня известен только один рукописный экземпляр этого произведения, хранящийся в упомянутом фонде под номером №2702.

Кроме того, известные такие тафсиры как «Тафсир-и сура-и Фатиха» и «Тафсир-и сура-и Юсуф», автор которого Муъиниддин Мухаммад ибн Шарафиддин хаджи Мухаммад Фарахи Хирави (ум.1501-1502), исполнявший в свое время обязанности казия в Герате. «Тафсир-и сураи Юсуф» является комментарием 12-суры Корана, комментирование которой превратилась среди исламских ученых в традицию[19].

Хусейн Ваиз Кашифи (ум. 1505), являвшийся современником Алишера Наваи и который жил и творил Герате, также является авторов нескольких комментариев к Корану как «Джавахир ат-тафсир ли тухфат ал-амир» («Драгоценный тафсир, являющийся подарком Амиру (Алишеру Наваи)»), «Мухтасар ал-джавахир» («Сокращение драгоценности»), «Джамиъ ус-ситтин йа тафсир-и сураи Юсуф» («Сборник шестидесяти глав или комментарий суры Юсуф»), «Мавахиб-и Алийя» («Дары Али(шеру)»). Среди них широкое распространение в мусульманском мире под названием «Тафсир-и Хусейни» получило произведение «Мавахиб-и Алийя»[20-21].

\section{Заключение}

Из приведенных выше сведений становится известным, что начиная с IX века в Центральной Азии под различными названиями был создан ряд тафсиров, отличающихся друг от друга по объему. Несмотря на то, что они известны научной общественности, некоторые из них до сих пор остаются неизученными. Исследование этих тафсиров имеет важное значение в изучении развития науки в регионе и определении вклада, которые местные ученые сделали для исламских наук.

\section{References:}

1. Ziyotov, S. (2003). Abu Mansur al-Moturidiy yozma merosi va uning "Kitob at-ta'vilot" asari. Tarikh fan. nom. il. dar ol. uchun yozilgan diss. - Tashkent, p.42.

2. Abdullaev, A. (2003). Abu Lays Samarqandiy "Bahru-l-ulum" asarining qolyozma nuskhalari / Tarikhiy manbashunoslik muammolari. Respublika ilmiy-amaliy anjumani materiallari. (pp.57-59). Tashkent: Universitet.

3. Obidov, R. (2003). Quran, tafsir va mufassirlar. (pp.210-215). Tashkent: Movarounnahr.
4. Uvatov, U. (2001). Mahmud az-Zamakhshariy. Ma'naviyat yulduzlari. (pp.132-137). Tashkent.

5. Sulaymonova, N. (2002). Al-kashshof Qurani karimning mukammal tafsiri sifatida. Imom Buxoriy saboqlari. Tashkent, №4, p.18.

6. Khalidov, B. Z. (1965). Zamakhshari (o jizni $i$ tvorchestve)", Semitskie yaziki. (pp.542-556). Moscow, II.

7. Khalidov, B. A., \& Khalidov, B. Z. (1979). "Biografiya az-Zamakhshari, sostavlennaya ego sovremennikom al-Andarasbani», Pisimennie pamyatniki Vostoka. (pp.203-212). Leningrad. 


\begin{tabular}{llllll} 
& ISRA (India) $=\mathbf{3 . 1 1 7}$ & SIS (USA) $=\mathbf{0 . 9 1 2}$ & ICV (Poland) & $\mathbf{= 6 . 6 3 0}$ \\
Impact Factor: & ISI (Dubai, UAE) $=\mathbf{0 . 8 2 9}$ & PUHЦ (Russia) $=\mathbf{0 . 1 5 6}$ & PIF (India) & $=\mathbf{1 . 9 4 0}$ \\
& GIF (Australia) $=\mathbf{0 . 5 6 4}$ & ESJI (KZ) & $\mathbf{8 . 7 1 6}$ & IBI (India) & $=\mathbf{4 . 2 6 0}$ \\
& JIF & $\mathbf{1 . 5 0 0}$ & SJIF (Morocco) $=\mathbf{5 . 6 6 7}$ & OAJI (USA) & $\mathbf{0 . 3 5 0}$ \\
\hline
\end{tabular}

8. Rezvan, E. A. (2001). Koran i ego mir. (pp.281282). Sankt-Peterburg.

9. Agius, D. A. (1982). Some bio-bibliographical notes on Abul Qasim Mahmud b.Umar alZamakhshari. Al-Arabiyya, XV/1-2, pp.108-120.

10. Brockelman, C. (1937). Die Geschichte arabischen literatur. Leiden, T.I. p.507.

11. (1954). Sobranie vostochnix rukopisey (SVR). (p.426). Tashkent, IV: Izdatelistvo Akademii Nauk UzSSR.

12. (n.d.). Rukopisi IVAN RUz №3601. SVR T. IV. p. 55.

13. Obidov, R. (n.d.). Qur'on, tafsir va mufassirlar. pp.148-151.

14. (n.d.). Rukopisi IVAN RUz: № 4017\2, № 2597\3, № 2819, №2563\1, №1698; SVR №№ 2888-2892.
15. (n.d.). SVR, T. IV, №2888.

16. Bo'riev, O., \& Hasanov, M. (2001). Xoja Muhammad Porso // Markaziy Osiyolik mashhur siymolar, allomalar, adiblar. (pp.200204). Tashkent, A.Qodiriy,

17. Hasanov, M., \& Bo'riev, O. (1996). Ya'qub Charxiy. Buyuk siymolar, allomalar. (p.45). Tashkent, A.Qodiriy nashriyoti.

18. (n.d.). SVR IX tom, p.435, №6642-№6661.

19. (n.d.). Naprimer "Bakhr ul-mavvoj" i “Jome' assittiyn".

20. Qayumov, A. P. (2001). Navoiyga bag 'ishlangan tafsir // Imom al-Buxoriy saboqlari. №2, pp.120122.

21. Munirov, Q. (2004). Tafsiri Husayniy" asarining qo'lyozma va bosma nuskhalari haqida. Sharqshunoslik, №6, pp.197-201. 